\title{
The J. C. Penney Company And Sephora USA Partnership: A Case Study
}

\author{
Suresh Singh, Ph.D., Northeastern Illinois University, Chicago, USA
}

\begin{abstract}
J. C. Penney, one of America's largest department stores, and Sephora U.S.A. Inc., an affiliate of the French cosmetics chain, entered into a partnership in 2006. The agreement allowed Sephora to exclusively operate cosmetics stores within J. C. Penney stores and to service J. C. Penney online customers through a link from J. C. Penney web-site to Sephora web-site. The purpose of this case study is to stimulate a critical evaluation of the decision by these companies to enter into a partnership instead of a merger or an acquisition. The case can be used as a tool to facilitate broader discussion of various corporate strategies and their relative merits and demerits. The accompanying teaching note refers the reader to an analytical framework that can be used to determine when to go for corporate partnerships instead of mergers or acquisitions and applies that framework to this case.
\end{abstract}

Keywords: Corporate Partnership; Merger \& Acquisition; J. C. Penney; Sephora; Store Within Store

\section{INTRODUCTION}

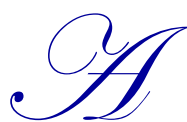

lliances and joint-ventures are corporate partnerships between two or more firms. The partners retain their separate identities but cooperate in areas of mutual interest. Partnerships are classified as equity or non-equity partnerships, depending on whether one or more partners hold shares in other parties involved. Corporate partnerships stand in contrast with mergers or acquisitions (M\&A's) where either two or more firms combine together (merger) or one or more firms take over a target firm (acquisition) to create a single firm. In the case of M\&A's, at least one party, if not both, loses its original identity. Both corporate partnerships and M\&A's are popular corporate strategies but more often than not these strategies result in failure. It is important, therefore, to be able to identify conditions under which partnerships make more sense than M\&A's and vice versa.

This case study is about the partnership between J. C. Penney Company, Inc. and Sephora USA, Inc. Readers are asked to evaluate the merits and demerits of the partnership from the perspective of each partner and ultimately to challenge the decision to partner instead of doing M\&A. The case also explores the pros and cons of having outside brands instead of private labels within a store like J. C. Penney and the attributes of product categories where outside brands are more likely.

\section{BACKGROUND INFORMATION}

This section provides a brief overview of Sephora and J. C. Penney and the context in which the partnership between these two companies was done.

\footnotetext{
About Sephora

Sephora is a chain of perfume and cosmetics stores, founded in France by Dominique Mandonnaud in 1970 (Sephora web-site). The company is owned by Louis Vuitton Moet Hennessy (LVMH), the world's leading luxury goods group. Sephora operates approximately 1,300 stores in 27 countries worldwide, including over 300 stores across North America. The company opened its first U.S. store in New York in 1998.
} 
Sephora sells a number of "classic and emerging brands across a broad range of product categories including skincare, color, fragrance, body, smilecare, and haircare, in addition to Sephora's own private label" (Sephora web-site).

\section{About J. C. Penney}

J. C. Penney is an American department store, headquartered in Plano, Texas. It started as a small dry goods store in Kemmerer, Wyoming in 1902 but today operates about 1100 stores (J. C. Penney web-site).

Despite its successes in other areas, the company struggled in the cosmetics department. In 2003, it ended its one and a half year partnership with Avon Products as part of a strategy to exit most of the cosmetics business and to focus instead on women accessories (Boswell, 2006; New York Times, 2003).

In late 2004, J. C. Penney hired Myron E. (Mike) Ullman as the chief executive officer (CEO). Mr. Ullman used to head LVMH, the owner of Sephora.

\section{THE PARTNERSHIP}

In April 2006, J. C. Penney announced a partnership with Sephora (J. C. Penney press release, 2006). According to the agreement, Sephora was to operate exclusive cosmetics stores within J. C. Penney stores and to cater to the needs of the online customers of J. C. Penney who were to be redirected from the J. C. Penney web-site to Sephora web-site. Each Sephora inside J. C. Penney was to retain Sephora's signature look and the people working in it were to be trained by Sephora. However, in contrast to its standalone stores of 4,400 square feet, Sephora inside J. C. Penney stores were to have a smaller footprint of about 1500 - 1800 square feet and to carry a limited selection (Karlin \& Bodamer, 2006).

Explaining the rationale behind the initiative, David Suliteanu, president and CEO of Sephora U.S.A said, "We see this initiative with JCPenney as a way to dramatically increase our retail presence, while we continue our core strategy of aggressively building free-standing stores across the country". He added, "JCPenney's focus on providing relevant merchandise to its broad customer base is consistent with our objectives. This includes America's youngest women, a market in which JCPenney is a significant and rapidly growing factor".

Myron E. Ullman, J. C. Penney chairman and CEO, said, "Our initiative with Sephora is a clear reflection of the transformation underway at JCPenney as we seek to build an emotional connection with our current customers and bring new customers into our stores and onto www.jcp.com. Our customer has been telling us that she wants a beauty and cosmetics selection that is new, exciting, and within her reach. There is simply no better partner to allow us to achieve that than Sephora, the most revolutionary, innovative retailer in the beauty industry. He later added during a conference call with investors, "Our customer spends approximately the same amount each year as the typical Sephora customer. She has the desire and the wherewithal to shop Sephora as it exists today". (Karlin \& Bodamer, 2006; Sephora website).

\section{DISCUSSION QUESTIONS}

1. What are the benefits and the pitfalls of the partnership between J. C. Penney and Sephora from the perspective of each partner?

2. Would a merger or an acquisition have been better?

3. What are the merits and the demerits of having outside brands within a store like J. C. Penney? Are there certain product categories that are more likely to be outsourced to outside brands as against having private labels?

\section{TEACHING NOTE}

After distribution of the case study and ensuring that participants had time to read it once, the facilitator of case discussion should first supplement the brief introduction of the key difference between corporate partnerships and M\&A's provided in the beginning of the case by providing definitions and examples of various corporate strategies (alliances, joint-ventures, mergers and acquisitions) to set the stage for specific discussion of the case. 
For the discussion of the potential benefits and pitfalls of the agreement for each partner, half the number of participants may be asked to assume the role of J . C. Penney senior management and the other half to assume the role of the senior management of Sephora. The arguments for the partnership are already reflected in the aforementioned statements of the CEOs of both companies. Sephora was looking for greater retail presence while J. C. Penney was after an established cosmetics brand that will fulfill the needs of its customers. Potential downside for Sephora was dilution of its luxury brand image and inferior customer experience in J. C. Penney stores due to limited selection of products as well as distraction from non-cosmetics merchandise and traffic. Potential disadvantages of the agreement for J . C. Penney included brand discordance in the mind of price sensitive customers as Sephora is a relatively more upscale brand (Boswell, 2006). The facilitator should note here that the companies tried hard to minimize these potential pitfalls by carefully considering the customer profile of both the companies and went ahead only after ensuring that the target customer segment is similar (young, able and willing to pay for new and exciting products) and that the agreement was one of the many steps taken by J. C. Penney to provide more upscale merchandise to this customer segment (Associated Press, 2006).

After a discussion of the relative advantages and disadvantages of the agreement from the perspectives of each company, the facilitator should encourage the participants to challenge the decision to partner and to evaluate M\&A as an alternative. The analytical framework proposed by Dyer, Kale \& Singh (2004) can be used to understand the conditions under which partnerships make more sense than M\&A's. The facilitator may assign this article as further reading to the participants and ask them to apply it to this case independently or simply provide a brief summary of the framework and show how it applies in this case. Table 1 should come in handy during this stage of the case discussion. The facilitator should emphasize that almost all the criteria laid out in the framework indicate that a corporate partnership between J. C. Penney \& Sephora was a better choice than M\&A.

Table 1 - Application of Dyer, Kale \& Singh's framework (2004) to the J. C. Penney - Sephora partnership

\begin{tabular}{|c|c|c|}
\hline Criteria \& prescribed strategy & $\begin{array}{l}\text { J. C. Penney-Sephora } \\
\text { partnership }\end{array}$ & Comments \\
\hline $\begin{array}{l}\text { Types of synergies } \\
\text { modular - nonequity alliances } \\
\text { sequential - equity alliances } \\
\text { reciprocal - acquisitions }\end{array}$ & modular & $\begin{array}{l}\text { no interdependence between cosmetics and other businesses } \\
\text { of J. C. Penney, very easy to dismantle partnership if no } \\
\text { success }\end{array}$ \\
\hline $\begin{array}{l}\text { Nature of resources } \\
\text { (relative value of soft to hard } \\
\text { resources) } \\
\text { low - nonequity alliances } \\
\text { low/medium - acquisitions } \\
\text { high - equity alliances }\end{array}$ & $\begin{array}{l}\text { - low for Sephora } \\
\text { - high for J. C. Penney }\end{array}$ & $\begin{array}{l}\text { - increased presence through J. C. Penney stores i . e. real } \\
\text { estate is more critical for Sephora } \\
\text { - Sephora's expertise and brand image is more critical for J. } \\
\text { C. Penney }\end{array}$ \\
\hline $\begin{array}{l}\text { Extent of redundant resources } \\
\text { low - nonequity alliances } \\
\text { medium - equity alliances } \\
\text { high - acquisitions }\end{array}$ & low & no assets to be divested after the agreement \\
\hline $\begin{array}{l}\text { Degree of market uncertainty } \\
\text { low - nonequity alliances } \\
\text { low/medium - acquisitions } \\
\text { high - equity alliances }\end{array}$ & low & $\begin{array}{l}\text { cosmetics industry is not new, no uncertainty of demand or } \\
\text { supply }\end{array}$ \\
\hline $\begin{array}{l}\text { Level of competition } \\
\text { (degree of competition for resources) } \\
\text { low - nonequity alliances } \\
\text { medium - equity alliances } \\
\text { high - acquisitions }\end{array}$ & low & $\begin{array}{l}\text { J. C. Penney can choose from a number of cosmetics brands } \\
\text { that other department stores carry. Similarly, Sephora can } \\
\text { also potentially join hands with other department stores. In } \\
\text { other words, not a do-or-die situation to take the risks } \\
\text { associated with acquisitions }\end{array}$ \\
\hline
\end{tabular}


Jerath \& Zhang (2010) provides clues to the third question. Store within store concept is more likely for product categories where customers perceive brand differentiation, cost of in-store services are high, potential of the outside brand to increase store traffic is high and inter-store competition is high. Cosmetics satisfy most of these criteria and this provides further reason as to why J. C. Penney's decision to allow Sephora full control of the cosmetics business within its stores was a good decision.

In the end, the facilitator may reveal that the partnership has been successful, as reported in the annual reports of J. C. Penney and as indicated by the proliferation of Sephora inside J. C. Penney stores (Table 2).

Table 2 - Growth in the number of Sephora inside J . C. Penney stores

\begin{tabular}{|l|c|c|c|c|c|c|}
\hline End of period & Oct 2006 & 2008 & 2009 & 2010 & 2011 & 2012 \\
\hline Number of Sephora inside J . C. Penney stores & 5 & 47 & 91 & 155 & 231 & 308 \\
\hline
\end{tabular}

Source: J. C. Penney annual reports

\section{AUTHOR INFORMATION}

Suresh Singh received his Ph.D. degree in business administration from the Ohio State University in 2011. He is currently an assistant professor of strategic management at the Northeastern Illinois University, Chicago, USA. His research interests are strategic management and international business. Suresh has been an assistant consultant with Tata Consultancy Services where he worked for six years. E-mail: $\underline{\text { S-Singh1@ @eiu.edu }}$

\section{REFERENCES}

1. $\quad$ Associated Press. (2006). J. C. Penney teams up with Sephora. MSNBC. Retrieved from http://www.msnbc.msn.com/id/12270549/ns/business-us_business/

2. Boswell, B. (2006). JCPenney moves upscale with Sephora as beauty brand. Shopping Centers Today by International Council of Shopping Centers. Retrieved from http://www.icsc.org/srch/sct/sct0506/retail_penney_sephora.php

3. Dyer, J. H., Kale, P. \& Singh, H. (2004). When to ally and when to acquire. Harvard Business Review, 82(7-8), 109-115.

4. J. C. Penney press release. (2006). Retrieved from http://ir.jcpenney.com/phoenix.zhtml?c=70528\&p=irolnewsArticle \&ID $=841663$ \&highlight $=$

5. J. C. Penney web-site. Retrieved from http://www.jcpenney.net/about/default.aspx

6. Jerath, K., \& Zhang, Z. H. (2010). Store Within a Store. Journal of Marketing Research. 47(4), 748-763.

7. Karlin, B., \& Bodamer, D. (2006). J. C. Penney, Sephora make up a new strategy. Retailtraffic. Retrieved from http://retailtrafficmag.com/news/penney sephora alliance

8. New York Times. (2003). Company news; J. C. Penney and Avon end cosmetics partnerships. New York Times. Retrieved from http://www.nytimes.com/2003/02/01/business/company-news-jc-penney-and-avonend-cosmetics-partnership.html

9. Sephora web-site, Retrieved from http://www.sephora.com/contentStore/mediaContentTemplate.jsp?mediaId=10000020 